\title{
DEVELOPMENT AND SUBJECT FOR PARTNERSHIP BETWEEN STALLHOLDERS AND CRUMB RUBBER FACTORIES IN INDONESIA RUBBER MARKETING
}

\author{
Husin Laila*, Yulius, Bidarti Agustina, Antoni Mirza \\ University of Sriwijaya, Indonesia \\ *E-mail: elahusin2007@yahoo.co.id
}

\begin{abstract}
The research aims to identify constraints in developing the marketing pattern of rubber in partnership. The study was conducted on 12 processing and marketing units (PMU) of rubber material which were divided into 6 each applying partnership marketing patterns and 6 non partnerships, 9 crumb rubber factories consisting of 3 partnerships, the rest not implementing partnerships. 180 sample farmers who each applied partnerships and 90 did not implement partnerships. The method of research is in depth study by observing and interviewing to exploring the variety of reasons join or not in certain marketing pattern, advantage and disadvantage the farmers' decisions in form of marketing institution, which is partnership and non partnership. Data analyzed by using quantitative and qualitative descriptively method. The research result indicated that crumb rubber factories' reasons had not cooperated with in partnership pattern are (1) the difficulty in determining of the rubber material price, (2) the uncertained supply of farmer's rubber for factory, (3) the supply is often fulfilled by traditional marketing institution, the farmers is often not hold the agreement especially during the session of low rubber price, however the factory still give guidance and help the farmers as partnership member. This research result indicates that some farmer's reasons which had not cooperated with in partnership pattern are (1) it is the lower rubber material price by factories than by middlemen, (2) PMUs is not active any more, (3) the farmers have illegal agreement in form of credit and paid by selling their product to the middlemen, (4) the payment duration of the farmer's product in auction system is too long according to the farmers and (5) the farmers often could not fulfilled selling quote of rubber material as determined in contract. The partnership members in this cooperation should discuss any problems to get good solution. The government sould always support and facilitate the commitment of partnership between the farmers and the crumb rubber factories to increase their performance in rubber marketing and to reduce any intervention from the outer institution (such as local marketing institution).
\end{abstract}

\section{KEY WORDS}

Partnership system, crumb rubber factories, middlemen.

The Indonesia rubber industry has the big problem. It is marked by long marketing channel and many marketing institution. These characteristics will result inefficiency marketing system (Herdiansyah et.al, 2015; Sujarwo, 2015; Yuprin, 2009; Panjaitan et. al, 1993). This marketing system is known as a traditional marketing system.

In general, the rubber marketing in Indonesia can be categorized into two marketing systems, that is organized marketing system and traditional marketing system (Dinas Perkebunun Provinsi Sumatera Selatan, 2014). The organized marketing system is the rubber marketing pattern where the farmer sell their product through their farmer's group, the village unit cooperation (KUD) or PMU and then to marketing institution or rubber processing factory. PMU is the processing and marketing unit of rubber material. The traditional marketing channel is the rubber marketing pattern where the farmer individually sells their product to marketing institution directly.

The organized marketing channel has built firstly when the government developed the Nucleous Estate Smallholder (NES) Partnership Pattern in 1977 and Smallholder Rubber Development Projcet (SRDP) in 1980. Those programs have also developed KUD as farmer marketing media to sell their products to the Nucleous Estate (corporation), marketing 
institution or crumb rubber industry. Unfortunately, these patterns are not sucsessfull due to the limited areas to develop the KUD. Eventhough some KUDs are still exist until now at the same number. Actually the quality of Indonesia rubber is relatively low, in form of latex or crumb rubber compare to the government competitiors such as Thailand and Malaysia (Asmara and Hanani, 2012), therefore since 2008, the government has developed some policies to overcome this problem and one of them is to establish the PMU. There had been developed 388 PMU until 2017, this number is still small, that is only $1.25 \%$ of the potential PMU. It shold be developed one PMU for each100 ha area of rubber plantation.

Mostly, rubber marketing by KUD and PMU done by auction system, in form of spot or forward auction. Only a few of PMU do rubber marketting by using partnership pattern. The buyers of auction marketing are marketing institution, whereas the buyers of partnership marketing are crumb rubber factories. According to Husin et al (2017) partnership marketing system can give higher income to farmers compare to auction marketing especially by traditional marketing system.

The channel of partnership marketing is shorter than others, the price determined based on real Dry Rubber Content (DRC). In case of South Sumatera, as the biggest rubber producer in Indonesia, it is only 4 (total 28 units) crumb rubber factories (14.28\%) applied the partnership pattern, where 3 factories in one group. Until now, it has not studied yet the study about the reasons so they (farmers, farmer group, PMU or KUD) have not applied yet this partnership system. As we know, this partnership pattern is profitable for all. If the farmer sell the product directly to crumb rubber factory, so the price valued based on DRC so that the price is higher. Besides that, crumb rubber factory got benefit due to the guarantee of material supply, eventhough there is unstable demand condition, especially for excess demand so that the factory operate only $49 \%$ process capacity. Therefore, it is important to study why the partnership pattern has not developed yet well and what the reasons are.

\section{METHODS OF RESEARCH}

Survey was done at 12 PMU, 180 farmers and 9 crumb rubber factory in South Sumatera. The province of South Sumatera choosen due to as the biggest rubber producer in Indonesia, and then choosen 3 districts which have cooperation between factory and PMU in form of partnership, that is Musi Rawas, Musi Banyuasin and Muara Enim. From 12 PMU divided by 2 groups, partnership and non partnership system. Each district choosen 90 farmers and 2 PMU for each different marketing system, 2 crumb rubber factories for Muba and Muara Enim 3 crumb rubber factories in Palembang. The research data processed and reported by using table, and then analyzed and descripted quantitatively and qualitatively

\section{RESULTS AND DISCUSSION}

The Reasons of Participation Agents in Partnership System. Right now, there is only a few of crumb rubber factories still participated in partnership pattern with the farmers or farmer group. Table 1 below presented some reasons about their decisions to participate or not in partnership pattern when they do the rubber marketing

Table 1 - The Reasons of Factory's Decision in Rubber Marketing System

\begin{tabular}{l|l|l}
\hline Participation in Partnership System & Not Participation in Partnership System & $\begin{array}{l}\text { Stop Participation in } \\
\text { Partnership System }\end{array}$ \\
\hline $\begin{array}{l}\text { 1) recommended by government through } \\
\text { Plantation institution (Dinas Perkebunan) }\end{array}$ & $\begin{array}{l}\text { 1) it is hard to keep the agreement of the } \\
\text { rubber price level }\end{array}$ & $\begin{array}{l}\text { 1) the rubber price level } \\
\text { tends lower continously }\end{array}$ \\
\hline $\begin{array}{l}\text { 2) the obligation to develop the } \\
\text { community and traditional plantation }\end{array}$ & $\begin{array}{l}\text { 2) the factory still can purchase directly } \\
\text { to another marketing institution (local } \\
\text { traders) }\end{array}$ & - \\
\hline $\begin{array}{l}\text { 3) control and maintanance the rubber } \\
\text { supply for factory }\end{array}$ & - & - \\
\hline $\begin{array}{l}\text { 4) to keep the good relationship between } \\
\text { rubber factory and farmers }\end{array}$ & - & - \\
\hline
\end{tabular}


Based on data presented on Table 1 above, there are 4 (four) reasons why they participate in partnership system, and 2 (two) reasons why they are or not participation at all and only 1 (one) reason why they are not participate any more (stop participating) in partnership system.

From 4 (four) rubber factory's reasons of participation in partnership pattern, there is only one reason is recommended by the local government institution (Dinas Perkebunan), but the others are from the factory's inisiative, that is to help the farmers and the rubber community, to keep the rubber supply and good relationship with the farmers.

The big problems of sustainable partnership system are: (1) it's hard to determine the rubber price and (2) it's easy to purchase the rubber from the local trader directly. Finally, the farmer's reason of unparticipant in partnership system is the rubber price often lower and lower continously. These factors need to be solved, especially in agreement of rubber selling price, where the PMU's selling price in partenship system tends lower than the local trader's selling price (not in partnership system).

As we know the marketing channel of partnership system is shorter (Farmers $\rightarrow$ crumb rubber factories), theoritically the marketing margin and marketing cost is smaller, so that the farmer as rubber producer (in partnership system) can take the higher price, because the marketing system is more efficient. If the partnership rubber price can be set higher, so that the rubber factory don't worry about the rubber supply, it can be fulfilled directly by PMU, KUD or farmer group in partnership system. According to the crumb rubber factory, there are some the advantages and disadvantages got in rubber marketing by participating in partnership system, presented on Table 2 .

Based on the data above (Table 2), the advantages to participate in partnership system actually are more than the disadvantages, where there are 13 advantages and only 3 disadvantages by participation in this partnership system.

There are many advantages (13 points) for rubber factory as participant in partnership system. In general, this pattern can guarantee rubber supply for processing in crumb rubber factory in good quality and quantity. It means that the sustainability of rubber factory will be guarranted, the rubber processing cost can be pressed, the rubber factory can operate efficiently, therefore they support the government program to achieve good and clean processed product (crumb rubber).

Table 2 - Advantage and Disadvantage the Factory by participating in Partnership system

\begin{tabular}{l}
\hline Advantage \\
1). This partnership system can support the government \\
program \\
\hline 2). Farmers can produce the high quality product (in form of \\
crumb rubber/slab) \\
3). The rubber processing guidance by factory to the farmers \\
can be implemented faster \\
\hline 4). Increase the selling price of crumb rubber such as increase \\
the quality of product \\
\hline 5). Simplify the complicated marketing channel \\
\hline 6) The factory can get the good quality of crumb rubber from \\
the farmers \\
\hline 7). The factory is able to develpod/invest for skilled farmers \\
\hline 8). Guarantee the sustainability of rubber supply (from \\
farmers) to factory \\
\hline 9). The farmers can be easier to be educated to produce the \\
quality crumb rubber by the factory \\
\hline 10). It can help making the easier rubber processing system \\
\hline 11). It can help setting the lower rubber processing cost \\
\hline 12). It can guarrantee the rubber quantity /supply distribute to \\
the factory more accurately \\
\hline 13). The factory can help giving the knowledge about the good \\
rubber processing to the farmers \\
\hline
\end{tabular}
Disadvantage

1). The partnership agreement between factory and farmers are often not commited especially for the farmers in selling the rubber to the factory

2). The factory's limitation to get the rubber supply from non participant farmers 3). These participants always claim to each other partner in implementing the partnership's regulation 
From the disadvantages ( 3 points), only point 1 and 3 often become the factory's reasons is not participated in partnership system or not cooperated with the farmers and farmer groups. According the factories, they always commit but not the farmers for the partnership agreement, especially in selling the farmers'product (rubber) to other factory or local traders. However the farmers also complain about the lower rubber price determined by factory as participant in partnership system than other institutions, that is why they are not commited any more. The farmers choose to sell their product to non participant of partnership system, such as local traders. These marketing institutions like purchasing the farmers' rubber for higher price than partnership factory.

The Reasons of Agents are not participated in Partnership System. There are a lot of farmers and farmer groups don't sell their product (crumb rubber) in partnership system as government program, but they sell their product to traditional auction and traditional marketing system. As we know, the non partnership are still involved, the traditional marketing as local trader tends operate inefficient system than sell directly to the factory in the partnership system. The below table present some farmers'reasons not participate in partnership system.

Table 3 - The Farmer's and PMU's Reasons not as Participants in Partnership System

\begin{tabular}{|c|c|c|c|c|c|c|c|}
\hline \multirow{2}{*}{ Agents/District } & \multicolumn{7}{|c|}{ Number Agents not Partcipant Based on The Reasons (\%) } \\
\hline & $\mathrm{a}$ & $\mathrm{b}$ & $\mathrm{C}$ & $d$ & $\mathrm{e}$ & $f$ & $g$ \\
\hline \multicolumn{8}{|l|}{ Farmer } \\
\hline - Musi Rawas & - & - & - & - & 73 & 67 & 50 \\
\hline - Musi Banyuasin & - & 97 & 30 & - & - & 63 & 100 \\
\hline - Muara Enim & - & 100 & - & - & 73 & 17 & 60 \\
\hline Total & - & 66 & 10 & - & 49 & 49 & 70 \\
\hline \multicolumn{8}{|l|}{ PMU } \\
\hline - Musi Rawas & - & - & - & - & 100 & - & - \\
\hline - Musi Banyuasin & - & - & 100 & - & 100 & - & - \\
\hline - Muara Enim & - & 100 & 100 & 50 & - & - & - \\
\hline Total & - & 33 & 67 & 17 & 67 & - & - \\
\hline
\end{tabular}

Note:

a. No corporation participate in partnership system

b. The rubber price is not good, lower than non partnership system (auction/traditional marketing system)

c. The farmers are not sure to fullfill the selling quote to the factory as participant in partnership system

d. Determining the rubber quality is very selective and strictly

e. The farmers as debitor with local trader in traditional marketing system

f. Long payment system to the farmers's rubber

g. PMU stop operating for long time

Based on data presented on Table 3 above, the most farmers' reasons not participated in partnership system with crumb rubber factory $(70 \%)$ because of PMU are not active or not operated any more for long time, next reason $(66 \%)$ is The rubber price is not good, lower than non partnership system (auction/traditional marketing system), then next reason (49\%) are the farmers as debitor with local trader in traditional marketing system and long payment system to the farmers's rubber, and the least reason $(10 \%)$ is the farmers are not sure to fullfill the selling quote to the factory as participant in partnership system. The most PMU's reasons not active any more because it is lack of educating and controlling by government agent (Dinas Perkebunan). This institution prefers to achieve target quantity of PMU rather than quality of PMU. Besides that, the rubber price offered by Dinas Perkebunan is not interesting or lower than the non partnership system, such as in auction system or traditional system (local trader). In fact this marketing system has shorter channel, it means lower marketing margin and marketing cost. Therefore the rubber price in producer or PMU level should be higher not lower than the same price in different channel or longer marketing channel, that is non partnership pattern.

Besides that, the most PMUs' reasons not participated in partnership system with crumb rubber factory (67\%) because of PMU are not sure to fullfill the selling quote to the factory as participant in partnership system and PMU as debitor with local trader in traditional 
marketing system. The next reason (33\%), the rubber price is not good, lower than non partnership system (auction/traditional marketing system), The least reason of PMU not interested participate in partnership system (17\%) due to the process of determining the rubber quality is very selective and strictly.

The problem of PMU about the quote of rubber supply to the factory, it can be solved by recruiting more farmers as PMU's member. However, the problem of PMU as debitor with local trader in traditional marketing system is still scarce or seldom happened, because it means the role f PMU not active any mopre as business unit. The ideal partnership system in rubber marketing system should give more benefit to the farmers. However, in reality, there are only small number of PMU are still active in partnership system, eventhough, it found that there are some PMUs are not participated any more or stopping in partnership system.

Below presented on Table 4, where there are some advantages and disadvantages according to PMU when they participate in partnership system. However there are more advantages (8 points) than disadvantages (5points), where the most benefit as participant of partnership system is getting the higher price, and then being freely to choose the rubber factoryto sell their product. The other benefit are relatively same frequence, such as it is easily accsess to get donation, it can increase farmers' experience, it makes shorter marketing channel, it is free from dependence, it has been promised to get rubber warehouse and got training from District Plantation Institution.

There are some disadvantages, such as the rubber drying process by using air fan seems take long time, the PMU's worrying can not fulfill daily rubber supply for factory, the PMU's rubber price depend on the factory's processed/crumb rubber, it has not available the solution yet for rubber price, It is scarce accessibility for donation.

Table 4 - Advantages and Disadvantages of PMU as Participant of Partnership

\begin{tabular}{l|l|l|l}
\hline Advantages & Frequency & Disadvantages & Frequency. \\
\hline Easily accsess of donation & 1 & $\begin{array}{l}\text { the rubber processing by air fan takes long } \\
\text { time }\end{array}$ & 1 \\
\hline Setting Higher Price & 3 & $\begin{array}{l}\text { Worrying not fulfilled the raw rubber supply } \\
\text { for factory daily }\end{array}$ & 1 \\
\hline Increasing Farmers' Experience & 1 & $\begin{array}{l}\text { The PMU's rubber price depend on the } \\
\text { factory's processed/crumb rubber }\end{array}$ & 1 \\
\hline Doing shorter marketing Channel & 1 & $\begin{array}{l}\text { not available the solution yet for rubber } \\
\text { price }\end{array}$ & 1 \\
\hline It is Free from Dependence & 1 & scarcity for donation accesesibility & 1 \\
\hline $\begin{array}{l}\text { Choosing the rubber Factory who give } \\
\text { higher price freely }\end{array}$ & 2 & & \\
\hline $\begin{array}{l}\text { Being Promised to get rubber } \\
\text { warehouse by District Plantation Agent }\end{array}$ & 1 & & \\
\hline $\begin{array}{l}\text { Getting training from District Plantation } \\
\text { Institution }\end{array}$ & 1 & & \\
\hline
\end{tabular}

There are interesting facts, some contradictive reasons of participating in partnership system according to PMU and farmers (Table 3 and 4). The reason, especially for point of higher price and freely choose the factory who want to buy the rubber with higher price. However, the PMU's reasons of not participated in partnership (Table 3 ) is mostly because of the lower price from the factory. It seems that there are some contradictive reasons between PMU and farmers about the rubber price set by rubber factory. The information of farmer's reason on Table 3 about the lower rubber price (set by the rubber factory) may be from the farmers who participate in partnership system, not based on their experiences. Differently the PMU's reasons (Table 4), it is based on their experiences. Therefore, it is better used the last information or the information from the PMU's reasons on Table 4, because the information come from the primer source (PMU's) as respondents in this study. Meaningly, the partnership pattern in rubber marketing system gives benefits especially in increasing the rubber price for PMU and farmers.

The other uncommon advantages are the PMU can sell their product freely to many factories who can give the highest price. It is not committed with the partnership agreement. 
This fact can cause the rubber factory is not interested any more to keep the agreement with the PMU. They have done some programs to help the PMU and farmers to increase their performance, such as give the training about good practice of rubber cultivation and processing.

\section{CONCLUSION}

The reason many crumb rubber factories do not have partnerships with rubber farmers or farmer organizations is because it is difficult to make a deal on the purchase price of rubber by the factory, besides the factories can directly buy with middlemen. This problem must be facilitated by the government. Farmers often consider partner buying prices to be no better, sometimes even lower than the buying price by middlemen. Even though the partner crumb rubber factories has determined the price based on DRC, both real measured in the laboratory and estimates are more accurate than the DRC on the auction market, even traditional marketing systems. Indeed, even though the factory purchase price is based on $\mathrm{DRC}$ and refers to international prices, the factor of production costs and factory profits should be more open crumb rubber factories with farmers.

Many crumb rubber factories do not want to partner because besides they have a fixed supplier in the form of middlemen, also because partner farmers often demand and often break promises with an agreed contract, namely by selling to other places if prices do not benefit farmers. Even though, the company has provided guidance and assistance.

Another reason for farmers not to join in partnership is because PMU does not operate actively, is tied to debt with middlemen, the payment duration of the farmer's product in auction system is too long according to the farmers. Therefore the crumb rubber factories and the farmers who make the partnership should discuss issues that hinder the farmers' lack of commitment to the principles of partnership. The government is pushing more and more partnerships between farmers and factories to reduce the role of middlemen in smallholder rubber marketing.

\section{AKCNOWLEDGEMENTS}

This paper is part of the Grant Competitive Universitas Sriwijaya Research in 2018, which has been funded this research complies with the letter of Agreement Assignment of Competitive Grants Research Universitas Sriwijaya in 2018.

\section{REFERENCES}

1. Asmara, R., and N. Hanani. (2012). Komparasi transmisi harga karet alam Indonesia dengan Malaysia and Thailand. Retrieved from http://nuhfil.lecture.ub.ac.id/files/2012/12/jurnal- karet-perhepi-nuhfil-rosihan-final2.pdf

2. Dinas Perkebunan Provinsi Sumatera Selatan. 2014. Pola Pengembangan Pemasaran Komoditi Karet Sumatera Selatan. Palembang.

3. Herdiansyah, R. et al. 2015. Sistem Pemasaran Karet Rakyat dengan Pendekatan Food Supply Chain Network (FSCN) di Kabupaten Tebo, Jambi. Prosiding Seminar Nasional. Kristalisasi Paradigma Agribisnis dalam Pembangunan Ekonomi and Pendidikan Tinggi. IPB International Convention Center, Bogor 18 April 2015. Page:545-562

4. Husin L., Yulius, Adriani D., and Antoni M. 2017. Effect of Different Rubber Market System on Farmer's Income in South Sumatra Province, Indonesia. Russian Journal of Agricultural and Socio- Economic Sciences (RJOAS), 11(71):257-262.

5. Sujarwo, R.M. 2015. Marketing System of Smallholder Rubber in the Jambi Province, Indonesia. Graduate School Bogor Agricultural University Bogor.

6. Yuprin. 2009. Analisis Pemasaran Karet di Kabupaten Kapuas. 2009. Jurnal Wacana. 12(3):519-538.

7. Panjaitan, L. et al. 1993. Efisiensi Pemasaran Karet Rakyat di Provinsi Kalimantan Selatan. Buletin Perkaretan, 11(1-3):37-51. 